\title{
FATIGUE BEHAVIOR OF HIGH STRENGTH AL-CU-MG AND AL-CU-LI ALLOYS JOINTS OBTAINED B Y FUSION AND SOLID STATE WELDING TECHNOLOGIES
}

\author{
Illia KLOCHKoV*, ANATOLIY PoKLAYTSKy, \\ SVIATOSLAV MOTRUNICH \\ E.O. Paton Electric Welding Institute of the National Academy of Science of \\ Ukraine, 11 Kazymyra Malevycha street, 03150 Kyiv, Ukraine
}

[Received: February 27, 2018. Accepted: May 13, 2019]

doi: 10.7546/JTAM.49.19.02.07

\begin{abstract}
This paper presents analyses of strength characteristics and fatigue behavior of butt welded joints of $2 \mathrm{~mm}$ thickness high strength D16T1 ( $\mathrm{Al}-\mathrm{Cu}-\mathrm{Mg}$ ) and 1460T1 (Al-Cu-Li) aluminum alloys, produced by tungsten inert gas (TIG) welding and friction stir welding (FSW). It is shown that friction stir welded joints has minimal stress concentrations in places of transition from the weld to the base material and also have no defects in the joint such as oxide film macroinclusions and hot cracks caused by melting and crystallization of the metal in fusion welding. At that, severe plastic deformations of metal under tool shoulder and in weld core results in formation of fine grain (3-4 $\mu \mathrm{m}$ ), homogeneous disoriented structure and elongation and deviation of grains in a direction of plasticized metal movement take place in adjacent areas. Consequently, hardness and tensile strength of the joint weld metal are increased. Fatigue behavior under constant amplitude loading of FSW joints exceeds the characteristics of the joints obtained by TIG welding.
\end{abstract}

KEY WORDS: aluminum alloys, friction stir welding, defects, hardness, tensile strength, fatigue behavior.

The use of high strength and corrosion resistant alloys with low density and high elasticity modulus can reduce fuel consumption and improve the tactical and technical performance of the products in aircraft and space technology. Alloy D16T1 (density $2.8 \mathrm{~g} / \mathrm{cm}^{3}$ ) of Al-Cu-Mg doping system contains $3.8-4.9 \% \mathrm{Cu}$ and $1.2 \ldots 1.8 \% \mathrm{Mg}$ also known as 2024 by AISI classification. D16T1 commonly used in aircraft due to its high strength and fatigue resistance combined with low crack propagation rate. However, because of high possibility of crystallization cracks formation, it belongs to the categories of alloys that are hardweldable by fusion methods [1-3].

Alloy $1460 \mathrm{~T} 1$ is the high strength $\left(\mathrm{S}_{m}>500 \mathrm{MPa}\right.$, density $\left.2.6 \mathrm{~g} / \mathrm{cm}^{3}\right)$ alloy and belongs to $\mathrm{Al}-\mathrm{Cu}-\mathrm{Li}$ system (nominal composition $\mathrm{Cu} \approx 3 \%, \mathrm{Li} \approx 2 \%$ ) with

\footnotetext{
${ }^{*}$ Corresponding author e-mail: paton.testlab@gmail.com
} 
additions of zirconium and scandium. This alloy are similar to 2195 and 2090 alloys in AISI classification. High levels of strength and ductility of the alloy at cryogenic temperatures indicate the prospects of its use for manufacture of welded cryogenic tanks [4].

Various methods of fusion welding are used in the most cases for welding of aluminum alloys, in which melting a certain volume of materials being joined forms the joint and filler wire in a weld pool with subsequent crystallization in shielding inert gas. However, structural transformation and formation of typical defects such as pores take place in the weld metal and the near-weld zones if base material bands used as a filler material in fusion welding of aluminum alloys containing lithium. Application of filler wires provide for formation of thin thread oxide film macroinclusions in the bottom and along weld. This provides for necessity in technological measures aimed at improving the quality of surfaces to be welded and contributing to the intensification of weld pool metal mixing and activation the processes of destruction of oxide film. That's why the tensile strength of welded joints is $55 . .75 \%$ of that of base material parameter [4-6].

Friction stir welding (FSW) is used to avoid melting of the metal in the weld zone and get satisfactory properties of the welded joints in construction. Formation of the weld in this type of welding takes place in a solid phase, as a result of heating due to friction of small volume of metal to plastic state, its stirring along the whole thickness of welded edges and deformation in the closed space. That's why the FSW process has some significant advantages over fusion welding. Among them are formation of fine-grain structure of the joints, reducing the softening of materials being joined, preservation of the alloying elements, absence of typical defects and improving the mechanical properties of the joints [7-11]. Fatigue strength of different aluminum alloys made by FSW shows better results compared to fusion welding technologies [12-15].

The main purpose of this work is to establish the benefits of friction stir welding process compared to TIG welding of high strength aluminum alloys D16T1 and $1460 \mathrm{~T} 1$.

Sheets of high strength aluminum alloy D16T1 and 1460T1 of $2 \mathrm{~mm}$ thickness were used for studies. TIG butt joints were welded using $20 \mathrm{~m} / \mathrm{h}$ speed at 140 165A current on MW-450 machine ("Fronius", Austria). Bands of corresponding base material (to maintain the chemical composition of the weld metal similar to base material) and appropriate filler wires SvAMg63 and Sv1201 of $1.6 \mathrm{~mm}$ diameter were used as fillers. Friction stir welding was performed on equipment developed at the E.O. Paton Electric Welding Institute laboratory using a special tool (Fig. 1), rotation speed was $1420 \mathrm{rev} / \mathrm{min}$, and the linear movement speed made $13-14 \mathrm{~m} / \mathrm{h} \mathrm{[16].}$

Specimens (of $15 \mathrm{~mm}$ test portion width) from welded joints were produced ac- 


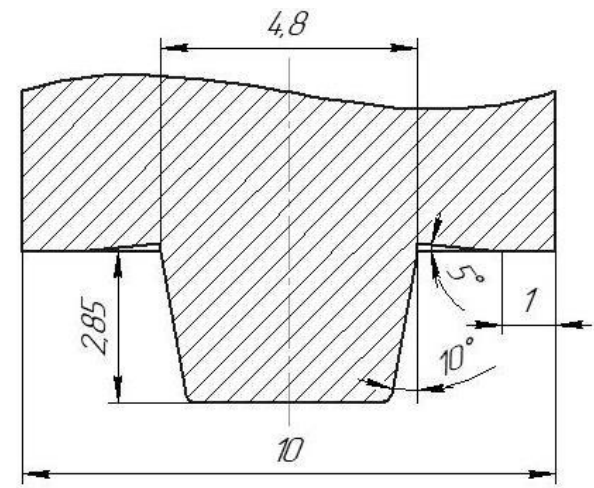

Fig. 1. Tool for FSW developed at the E.O. Paton Electric Welding Institute.

cording to ASTM in order to determine the tensile strength at uniaxial tension. The width of the test portion of the specimens for fatigue behavior determination was 25 $\mathrm{mm}$. Mechanical testing was performed on versatile servo-hydraulic complex MTS 318.25. The fatigue tests were carried out to fracture with stress ratio $R=0.1$ and $15 \mathrm{~Hz}$ frequency. A batch of 6-11 specimens of the same type were tested under the same conditions. The experimental data of fatigue tests were processed by linear regression analysis, generally accepted for this type of testing. The corresponding S-N curve, i.e. the line of regression of experimental data in $2 \sigma_{a}-\lg N$ coordinates was built based on the results of tests for each batch of specimens.

Hardness of metal was measured on joint face. The degree of metal softening in the weld zone was evaluated on "ROCKWELL" unit with $P=600 \mathrm{~N}$ load. Evaluation of structural peculiarities of the welds was performed using optical electron microscope MIM-8. The residual longitudinal stresses in the welded joints were determined experimentally by cutting method.

The studies show that the mechanism of friction stir joint formation is significantly different from the processes occurring during fusion welding. In FSW the joint is formed as a result of heating due to friction to plastic state, stirring and intense deformation of small volume of the metal of the parts being joined by special tool in the closed space without shielding gas and filler material.

Pin of the rotating tool being immersed between butt edges at the initial stage of welding displaces certain volume of plasticized metal. This metal can move only around the pin or go up, since its movement from the bottom is limited by a substrate and from the side by non-plasticized base metal. Further deepening of the tool results in complete contact of end operating surface of its shoulder with the material being welded and generated fully limited space, in which movement of plasticized 
metal takes place on complex trajectory, determined by geometry of pin operating surfaces and tool shoulder. When the tool starts making not only rotating motion, but also linear motion, then a zone of excessive pressure appears prior to its pin from the leading edge (where vector directions of rotation and linear motion of tool are matched). From it the pressure displaces to the trailing edge (opposite site, where indicated vectors have different directions) a thin interlayer of plasticized metal. Then, heated metal under pressure is pushed between welded metal and side surface of the pin from the trailing side into free space behind it, forming as a result of specific structure of the welded joints with pronounced weld nugget (D), formed as a result of dynamic resolidification (Fig. 2) zone of thermomechanical effect (C) is adjacent to it. In the latter the metal is subjected to plastic deformation in addition to heating. And heat-affected zone (B) comes after it, where structural changes of the base metal (A) are promoted only by temperature increase. The rotating and advancing motion of the tool along the joint forms advancing side (AS) and retreating sides (RS).

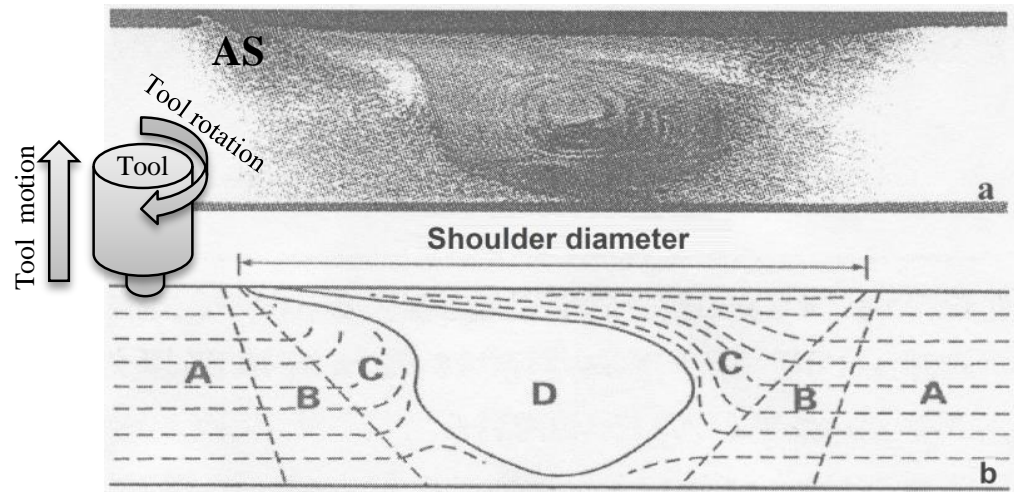

$\mathbf{R S}$

Fig. 2. Cross macrosection of FSW joint (a) and schematic representation of its characteristic zones (b).

Size of joint after friction stir welding is smaller and there is no weld reinforcement, formed by fusion welding due to welding wire, and penetration, due to the use of the substrate with the forming groove (Fig. 3). This allows avoiding significant stress concentration in a transition zone from the weld to the base material, which has negative impact on performance and life characteristics of the joint made by fusion welding technologies [17]. Besides, the formation of joint in the solid phase allows eliminating the defects usual for these alloys, i.e. pores and macroinclusions oxide films formed during fusion welding. The absence of molten metal, in which hydrogen solubility increases rapidly, prevent additional saturation of it in welding zone due to migration of the gas from the adjacent surface layers. 

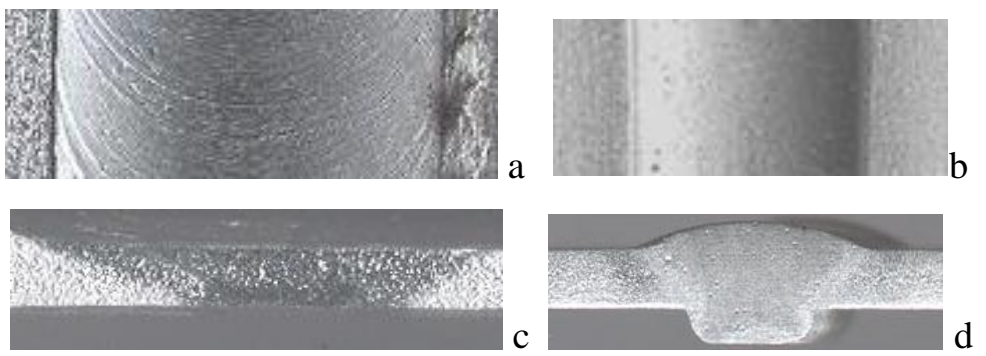

Fig. 3. Appearance of the front surface $(a, b)$ and cross sections $(c, d)$ joints of alloy D16T1 $2 \mathrm{~mm}$ thickness obtained by FSW (a, c) and TIG (b, d).

Intensive mixing and stirring of the plasticized metal along the whole thickness of the welded edges provides for breaking of oxide films located in them. Absence of molten metal in the zone of joint formation prevents its oxidation during the welding process. Therefore, in the joints, obtained by FSW, there are no defects in the form of separate and extended macroinclusions of oxide film typical for the joints made by TIG welding of high strength alloys (Fig. 4).
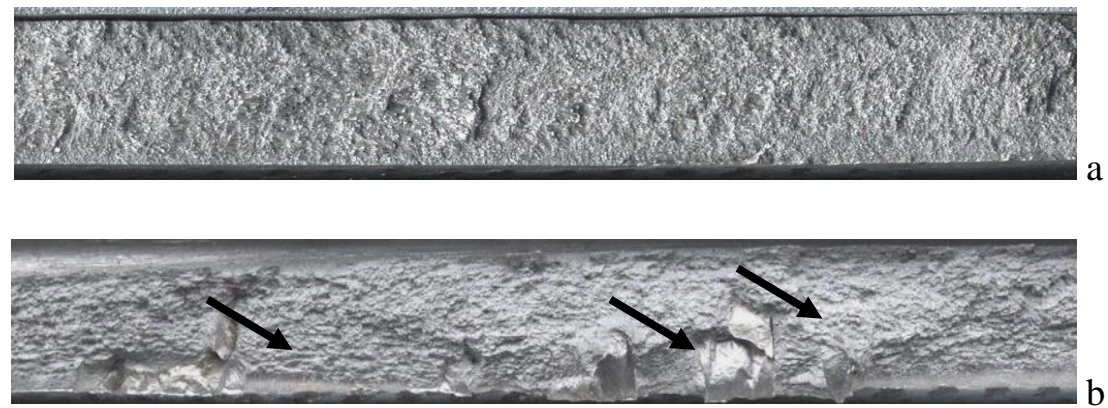

Fig. 4. Longitudinal fractures of welds from D16T1 alloy of $2 \mathrm{~mm}$ thickness, produced by friction stir (a) and TIG welding (b) with macroinclusions of oxide foil (indicated by arrows).

Reducing the temperature of edges heating and the formation of fine-grain structure of the weld in FSW the degree of metal softening is less than that in TIG welding. Thus, for alloy D16T1 the minimum hardness in the weld zone and its interface with the base metal is at the level of 97-98 HRB, whereas the minimum hardness of metal in the central part of the weld is near base material 103 HRB (Fig. 5). However, hardness in the middle of joint during TIG welding of D16T1 alloy reduces to 89 HRB.

Measurements of metal hardness in the 1460T1 alloy FSW welding joint show that it is also significantly higher than in TIG welding joints. Hardness of the welded 
184 Fatigue Behavior of High Strength Al-Cu-Mg and Al-Cu-Li Alloys Joints ...

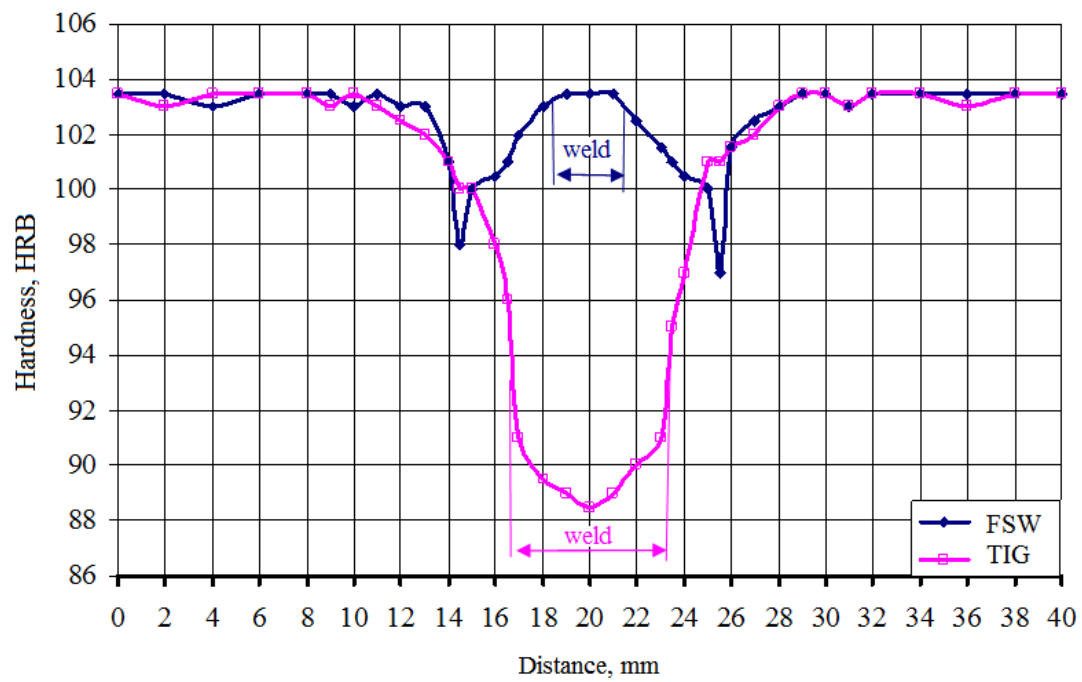

Fig. 5. (Color online) Distribution of hardness over the surface of D16T1 alloy welded joints of $2 \mathrm{~mm}$ thickness produced by TIG and the friction stir welding technology.

joint zone is up to $85-86$ HRB. While in TIG welding with Sv1201 filler wire the minimum hardness of metal in the central part of the weld is $71 \mathrm{HRB}$, and that in weld to base metal fusion zone makes $82-83$ HRB (Fig. 6).

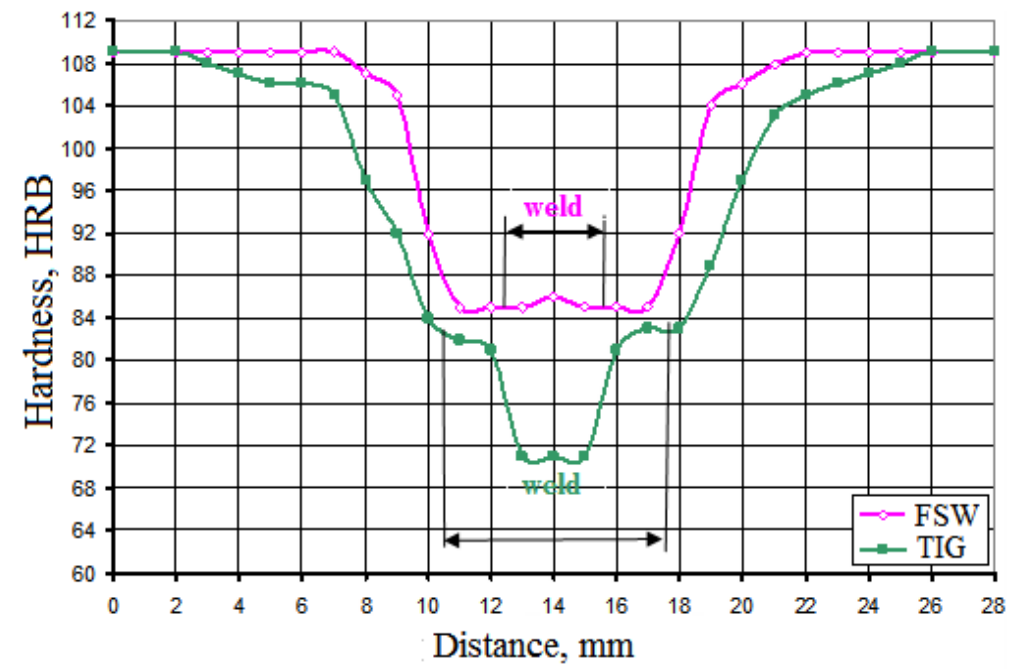

Fig. 6. (Color online) Distribution of hardness over the surface of $1460 \mathrm{~T} 1$ alloy welded joints of $2 \mathrm{~mm}$ thickness produced by TIG and the friction stir welding technology. 

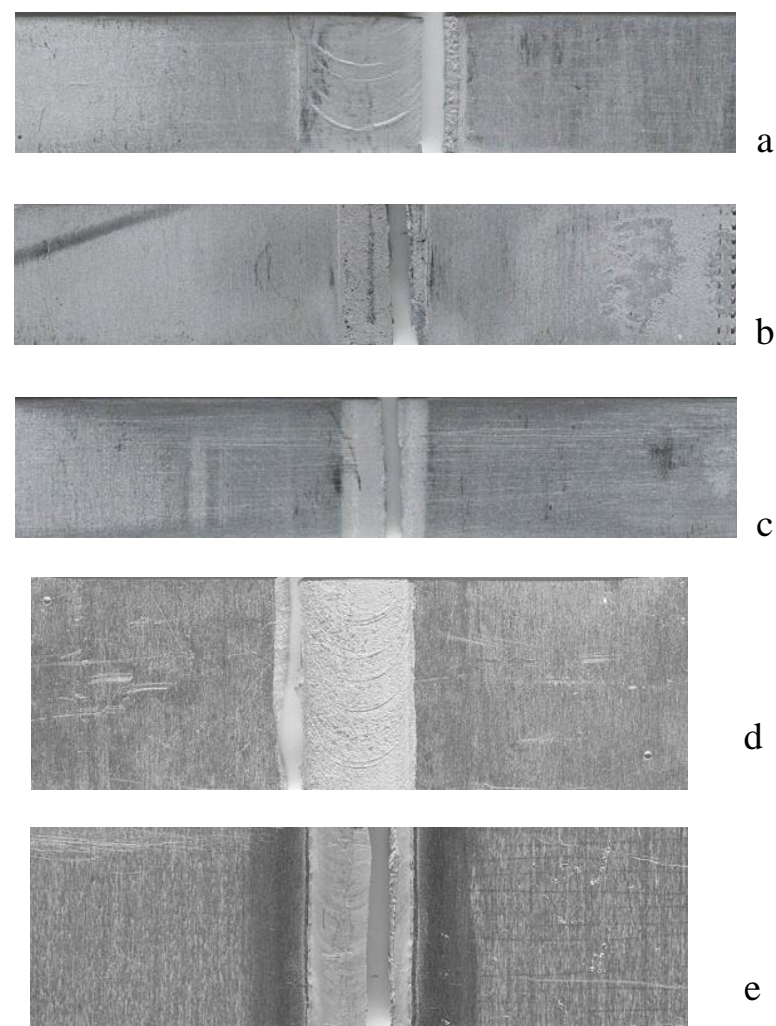

Fig. 7. Fragments of D16T1 specimens of welded joints produced by FSW (a, d) and TIG (b, $\mathrm{e}-$ with, $\mathrm{c}$ - without reinforcement) after tensile loading $(\mathrm{a}-\mathrm{c})$ and cyclic loading.

Therefore, specimens of such TIG welded joints without weld reinforcement fracture along the weld metal and have minimum tensile strength of $257 \mathrm{MPa}$. Fracture of the specimens with weld reinforcement takes place in weld to base metal fusion zone. Specimens of FSW joints fracture along the zone of thermomechanical affect from RS side.

However, their tensile strength is at the level of $310 \mathrm{MPa}$ as for specimens with weld reinforcement made TIG welding using Sv1201 filler wire. Tensile strength of specimens with weld reinforcement is average $297 \mathrm{MPa}$ when in use of strip of 1460T1 alloy base material as filler.

Samples of D16T1 welded joints obtained by FSW have the highest (425 MPa) tensile strength and fracture occurs along the zone of thermomechanical affect, where the metal has a minimum hardness. The minimum $(295 \mathrm{MPa})$ tensile strength is observed in the samples with the removed reinforcements in welds made by TIG. 
They fractured near the middle of weld, which has the least hardness and has cast microstructure. Samples with reinforcement have a tensile strength at the level of $330 \mathrm{MPa}$ and fracture occurs in the zone of fusion with the base material, where the maximum level of stress concentration arises (Fig. 7, a-c).

Experimentally obtained S-N curves of butt welded joints of aluminum alloys D16T1 and 1460T1 made by FSW demonstrate high levels of fatigue strength. Endurance strength of FSW joints of aluminum alloy D16T1 is $20 \%$ higher of the TIG welds and less only in $15 \%$ of the respective indices of base material in the entire region of durability of $10^{5}-2 \times 10^{6}$ cycles (Fig. 8). For 1460T1 alloy the corresponding figures of endurance strength are 20-25\% lower than the base metal (Fig. 9). For FSW joints of D16T1 and 1460T1 alloys the maximum stress range at $210^{6}$ cycles was $120 \mathrm{MPa}$ and $125 \mathrm{MPa}$, respectively. The maximum stress range of $1460 \mathrm{~T} 1$ alloy joints produced by TIG welding on the base of $2 \times 10^{6}$ cycles is $85 \mathrm{MPa}$, which is $30 \%$ lower than the corresponding values for FSW joints.

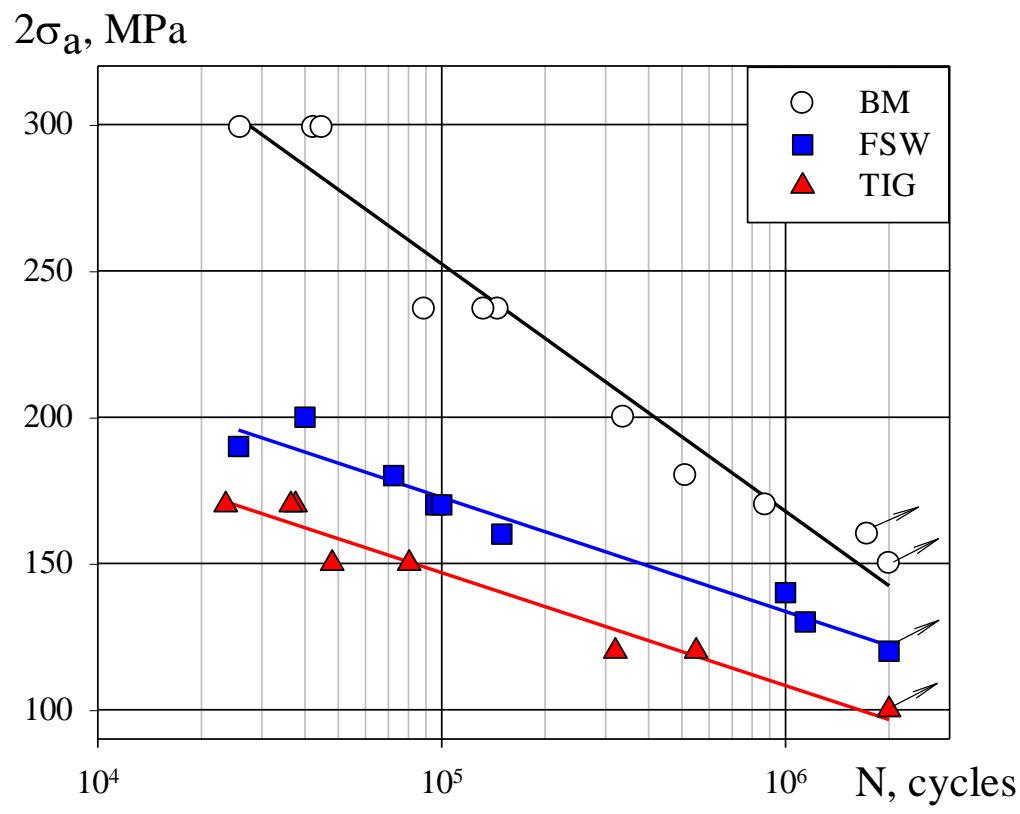

Fig. 8. (Color online) S-N curves of base metal and welded joints of $2 \mathrm{~mm}$ thick D16T1 aluminum alloy at stress ratio $R=0.1: \bigcirc$ - base metal; $\mathbf{\square}$ - FSW joint; $\boldsymbol{\Delta}$ - TIG joint.

Obtained results shows potential of using FSW technology for structures manufacturing where thin-sheets of high strength aluminum alloys are used and which are operated under cyclic loading. 
$2 \sigma_{\mathrm{a}}, \mathrm{MPa}$

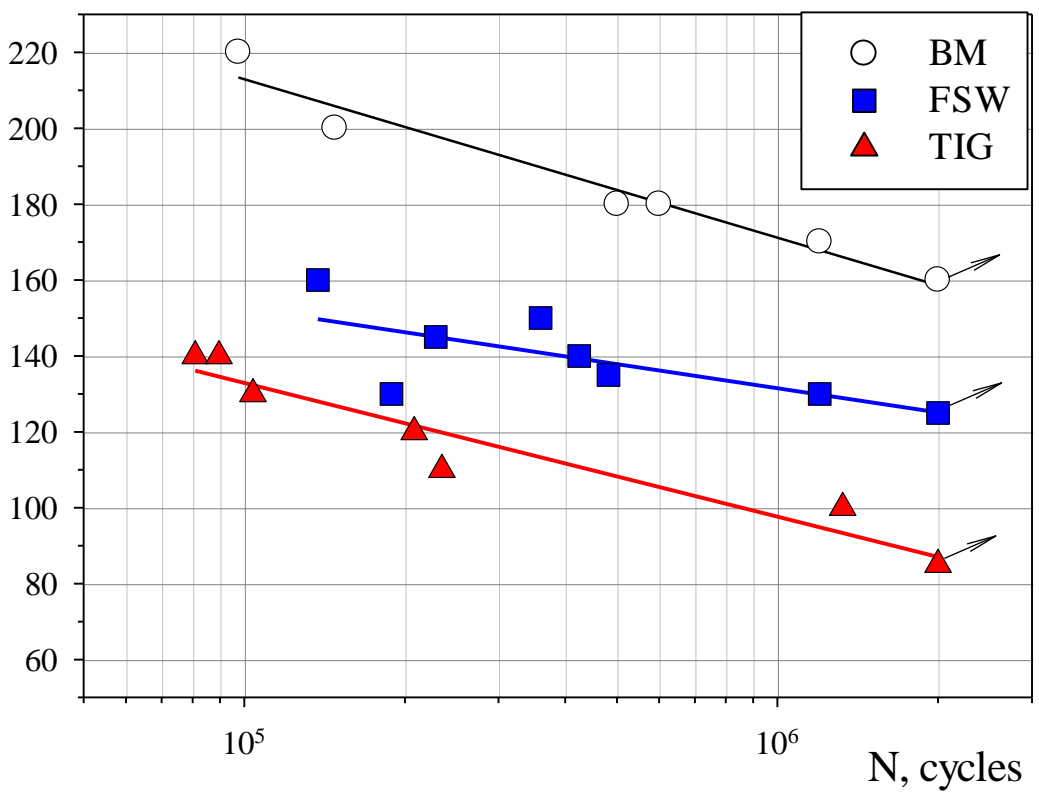

Fig. 9. (Color online) S-N curves of base metal and welded joints of $2 \mathrm{~mm}$ thick 1460T1 aluminum alloy at stress ratio $R=0.1: \bigcirc$ - base metal; - FSW joint; $\boldsymbol{\Delta}$ - TIG joint.

\section{CONCLUSIONS}

1. FSW technology provides for permanent joint formation with the minimum stress concentration in places of transition from the weld to the base metal and allows eliminating joint defects such as pores and oxide film macroinclusions that occurs due to melting and crystallization of metal in fusion welding.

2. Formation of FSW permanent joint in solid-state phase allows eliminating formation of cast coarse dendrite weld structure typical for fusion welding. At that, refinement of base metal grain and formation of new disoriented uniform grain size structure, with $3 \ldots 4 \mu \mathrm{m}$ grain size and dispersed $(\leq 1 \mathrm{~mm})$ phases precipitations, takes place around the tool pin, in the place of the most significant thermomechanical effect on the metal.

3. Thermomechanical affect in friction stir welding of heat-hardenable high strength alloys D16T1 and 1460T1 in addition to grain refinement in the welding zone, that promotes increase of metal hardness, provides for partial precipitation of proeutectoid constituents from the supersaturated solid solution and their coagulation. This leads to joint hardness decrease. However, the degree of metal softening in solid phase 
welding of D16T1 and 1460T1 alloys is significantly lower than in fusion welding. Therefore, tensile strength of the welded joints of these alloys, produced by the FSW, is higher than that in the joints without weld reinforcement made by TIG welding.

4. Fatigue tests confirmed the potential of FSW application instead of TIG in structures manufacturing where high strength D16T1 and 1460T1 alloys are used and which are operated under cyclic loading. It is shows that fatigue characteristics of the butt joints produced by FSW technology, exceed the corresponding indices of the joints made by TIG welding. The values of stress range at $2 \times 10^{6}$ cycles for FSW joints are only $15 . . .20 \%$ lower than base metal indices.

\section{REFERENCES}

[1] I.N. FRIDLYANDER (2005) "Alyuminiyevyye splavy v letatel'nykh apparatakh v periody 1970-2000 i 2001-2015. Tekhnologiya legkikh splavov". Spravochnik, K.: "KOMINTEKH".

[2] Ye.I. Shvechkov, V.V. Zakharov, T.D Rostova (2003) K voprosu o vybore marki alyuminiyevogo splava dlya obshivochnykh listov. Tekhnologiya legkikh splavov 1 17-21.

[3] V.M. BeletskiY, G.A. Krivov (2005) "Alyuminiyevyye splavy (Sostav, svoystva, tekhnologiya, primeneniye)". Spravochnik, K.: "KOMINTEKH".

[4] "Aviatsionnyye materialy" (2002) Izbrannyye trudy "VIAM" 1932-2002. Yubileynyy nauchno-tekhnicheskiy sbornik. M.: MISIS "VIAM" 198-220.

[5] A.G. BRATUKhIN (2003) "Sovremennyye aviatsionnyye materialy: tekhnologicheskiye i funktsional'nyye osobennosti". M: "Aviatekhinform".

[6] A. Lukianenko, T. Labur, A. Pokliatskiy, S. Motrunich, D. Bajic (2019) Investigation of fatigue strength and norms of emission of harmful substances in the air during MIG and TIG welding of 1460 aluminium-lithium alloy. FME Transactions 47 608-612.

[7] W.M. Thomas, E.D. Nicholas, J.C. Needham, et AL. (1991) Int. Patent Application No PCT/GB 92/02203; GB Patent Application No 9125978.8. Friction Stir Butt Welding - Publ.

[8] J. Defalco (2006) Friction Stir Welding vs. Fusion Welding. Welding Journal 3 42-44.

[9] K. Krasnowski, S. Dymek, C. Hamilton (2015) Influence of the Tool Shape and Weld Configuration on Microstructure and Mechanical Properties of the Al 6082 Alloy FSW Joints. Archives of Civil and Mechanical Engineering 15 133-141.

[10] М. Еломото (2003) Friction Stir Welding: Research and Industrial Applications. Welding International 5 341-345.

[11] S. Jannet, P.K. Mathews, R. Raja (2014) Comparative Investigation of Friction Stir Welding and Fusion Welding of 6061 T6-5083 O Aluminum Alloy Based on Mechanical Properties and Microstructure. Bulletin of the Polish Academy of Sciences: Technical Sciences 62(4) 791-795. 
[12] M. Ericsson, R. SAndstrom (2003) Influence of Melding Speed on the Fatigue of Friction Stir Welds, and Comparison with MIG and TIG. International Journal of Fatigue 25 1379-1387.

[13] K. Krasnowski, S. DymeK (2013) A Comparative Analysis of the Impact of Tool Design to Fatigue Behavior of Single-Sided and Double-Sided Welded Butt Joints of EN AW 6082-T6 Alloy. Journal of Materials Engineering and Performance 22(12) 3818-3824.

[14] A.G. Poklaytsky, I.N. Klochkov, S.I. Motrunich (2014) Structure and Properties of AMg2M Alloy Joints Made by Argon Nonconsumable-Arc Welding and Friction Stir Welding. Applied Mechanics and Materials 682 166-169.

[15] M. Uthayakumar, V. Balasubramanian, A.M.A. Rani, B. Hadzima (2009) Effects of Welding on the Fatigue Behaviour of Commercial Aluminum AA-1100 Joints. Presented at IOP Conference Series: Materials Science and Engineering 346, conference 1, ISSN:1757-8981; E-ISSN:1757-899X

[16] A.Y. Ishchenko, A.H. Poklyats'kyy (2010) Pat. 54096 Ukraine, MPK V23K 20/12. "Instrument dlya zvaryuvannya tertyam z peremishuvannyam alyuminiyevykh splaviv". Zayavnyk i patentovlasnyk IEZ im. YE.O. Patona NAS of Ukraine, No u201005315; zayav. 30.04.2010; opubl. 25.10.2010, Byul. No 20.

[17] A.V. Moltasov (2017) A Study of the Stress State in Stress Concentration Zones Under Tension of an Asymmetrically Reinforced Butt-Welded Joint. Strength of Materials 49 (5) $718-725$. 